\title{
Regulation and Function of Skeletal Muscle Stem Cells
}

\author{
M. Cerletti, ${ }^{*}$ J.L. Shadrach, ${ }^{*}$ S. Jurga, ${ }^{*}$ R. Sherwood ${ }^{\dagger}$ AND A.J. Wagers* ${ }^{*}$ \\ *Section on Developmental and Stem Cell Biology, Joslin Diabetes Center, Department of Stem Cell \\ and Regenerative Biology, Harvard University, and Harvard Stem Cell Institute, Boston, Massachusetts 02215; \\ Department of Molecular and Cellular Biology, Harvard University, Cambridge, Massachusetts 02138
}

\begin{abstract}
Skeletal muscle satellite cells, which reside beneath the basal lamina of mature muscle fibers, function as myogenic precursors and are required for normal muscle growth and repair. Satellite cells share a common anatomical localization, yet they exhibit substantial phenotypic and functional heterogeneity. Recent efforts in the field of adult myogenesis have been aimed at dissecting this heterogeneity and reveal the presence of discrete cell lineages within the muscle that function independently and interactively to maintain muscle homeostasis and to determine the outcome of muscle damage. Normal developmental regulation of the frequency and function of these distinct tissue precursors, and pathological deregulation of their activity, may have an important role in age- and disease-dependent loss of muscle regenerative activity.
\end{abstract}

\section{DEVELOPMENTAL ORIGINS OF SKELETAL MUSCLE AND SATELLITE CELLS}

Skeletal muscle is a highly specialized tissue composed of postmitotic, multinucleated muscle fibers that contract to generate force and movement. Skeletal muscle accounts for up to half the mass of human bodies, and, in addition to its role in voluntary and involuntary movement, has a critical role in maintaining metabolic health by regulating glucose uptake and insulin sensitivity.

During development, the cells that ultimately give rise to skeletal muscle are formed from paraxial mesodermderived cells of the dorsal somites (Buckingham et al. 2003). These cells are myogenically specified by signals emanating from neighboring cells of the notochord, neural tube, and dorsal ectoderm through the action of transcription factors such as the paired-box proteins $\operatorname{Pax} 3$ and Pax7 (Fig. 1) (Goulding et al. 1994; Cossu et al. 1996a,b; Borycki et al. 1999). Once committed to the muscle lineage, somite-derived cells migrate from the myotome to multiple sites of embryonic myogenesis, begin to express later markers of myogenic differentiation such as the basic helix-loop-helix transcription factors Myf-5 and MyoD (Birchmeier and Brohmann 2000) and the intermediate filament protein desmin, and differentiate into mature muscle fibers. Pax3 is required for appropriate establishment of limb muscles and regulates the migration of embryonic precursors from the somites to the limbs (Daston et al. 1996; Tremblay et al. 1998; Relaix et al. 2005). Studies of Pax7 "knockout" mice, on the other hand, suggest that Pax 7 is dispensable for prenatal muscle formation but required for normal postnatal muscle growth (Seale et al. 2000; Oustanina et al. 2004; Relaix et al. 2005).

Because mature muscle fibers are postmitotic, postnatal muscle growth and repair after injury depend on the maintenance of a reservoir of mononuclear muscle-precursor cells, which appear to be descended from $\mathrm{Pax} 3^{+}$ $\operatorname{Pax} 7^{+}$somite-derived progenitors that do not differentiate into myofibers during embryogenesis (Fig. 1) (Relaix et al. 2006). These progenitors form a pool of specialized muscle fiber-associated cells called satellite cells (Mauro 1961; Armand et al. 1983; Yablonka-Reuveni et al. 1987; Gros et al. 2005; Relaix et al. 2005) that contain the major regenerative activity for adult skeletal muscle (Mauro 1961; Collins et al. 2005). Satellite cells are found beneath the basal lamina and adjacent to the plasma membrane of mature muscle fibers (Fig. 2A) (Mauro 1961) and first appear in the limb muscles of mouse embryos between 16 and 18 days postconception ( $\mathrm{dpc}$ ). These cells

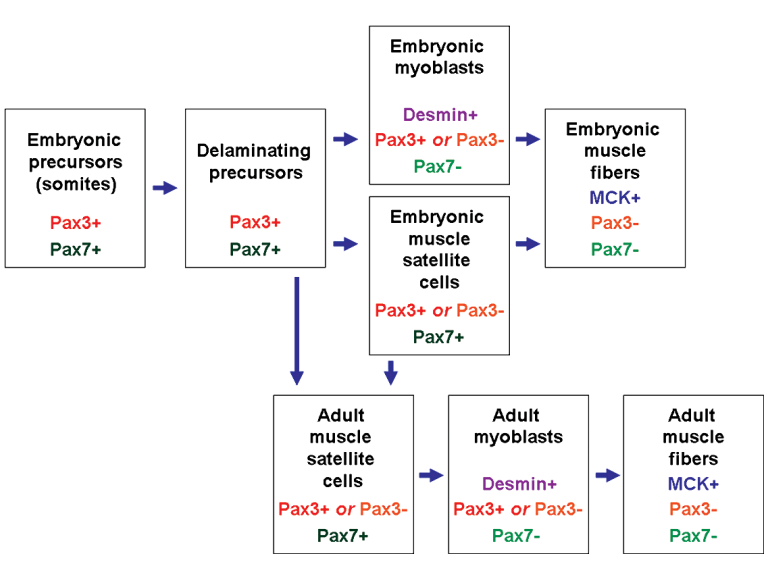

Figure 1. Myogenic gene expression in muscle precursors and differentiated muscle cells. The embryonic precursors of skeletal muscle originate in the somites and express Pax3 and Pax7. These precursors delaminate from the somites and migrate in a Pax3-dependent manner to multiple sites of myogenesis throughout the body. Embryonic myoblasts and satellite cells are formed from these precursors. Adult satellite cells arise either directly from the precursors or from embryonic satellite cells. Activation of satellite cells in adult muscle regenerates muscle fibers via production of more differentiated fusion-competent myoblasts. Cells at each stage of differentiation are specifically marked by unique expression of differentiation proteins; for example, expression of Pax proteins marks satellite cells and somitic precursors only, desmin marks myoblasts but not satellite cells, and muscle creatine kinase (MCK) marks fused myotubes and muscle fibers but not myoblasts or satellite cells. 
A

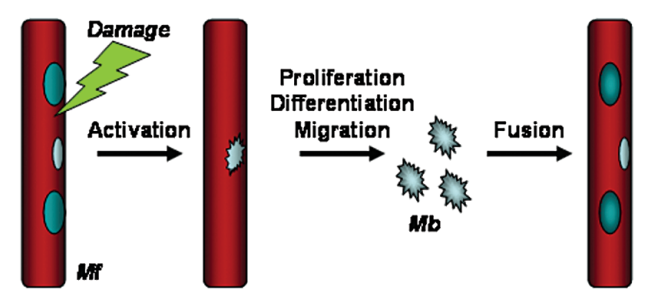

B Uninjured

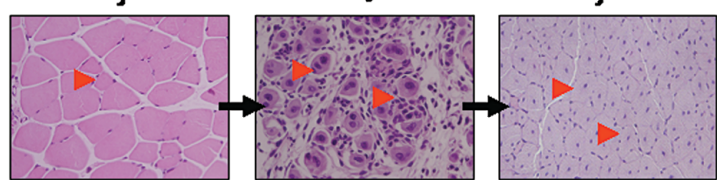

Figure 2. Normal muscle regeneration in young mice. $(A)$ Muscle repair by endogenous myogenic satellite cells (light blue). Satellite cells reside normally beneath the basal lamina of myofibers (Mf). Satellite cells are activated by muscle damage to proliferate, differentiate and migrate. Differentiation of satellite cells generates fusion-competent myoblasts $(\mathrm{Mb})$ that fuse with one another and with residual myofibers to repair muscle. Regenerated myofibers exhibit centrally located myonuclei (dark blue). Self-renewal of muscle stem cells reestablishes the satellite cell pool (light blue). (B) H\&E staining shows uninjured and regenerating muscle at 3 and 14 days after intramuscular injection of the snake venom cardiotoxin. Uninjured muscle shows characteristic peripheral nuclei (red arrowhead). Three days after injury, muscle shows extensive inflammatory infiltrate and some small regenerating fibers with characteristic centrally localized nuclei (red arrowheads). By 14 days after injury, the muscle is fully repaired, but regenerated fibers are still distinguishable by their central nuclei (red arrowheads).

are most abundant early in life, such that in neonatal mice, satellite cell nuclei comprise approximately $30 \%$ of myofiber-associated nuclei. However, satellite cell number declines with age, and only about $5 \%$ of myofiber nuclei in the muscles of adult mice represent satellite cells (Bischoff 1994).

\section{SATELLITE CELLS AND ADULT MYOGENESIS}

Normal skeletal muscle possesses remarkable regenerative capacity (Fig. 2B), and can undergo multiple rounds of rapid repair in response to injury. This regeneration appears to be mediated primarily by satellite cells, which are activated by muscle damage. Activated satellite cells proliferate, differentiate, and migrate to form fusion-competent myoblasts that fuse with residual myofibers and with one another to regenerate the muscle (Fig. 2A) (for review, see Wagers and Conboy 2005). This differentiation process invokes a well-studied cascade of myogenic regulatory factors that, in some regards, recapitulate molecular events of embryonic myogenesis (Fig. 1). Although normally highly efficient, in certain disease states, muscle regenerative activity can be impaired and, together with a loss of homeostatic muscle maintenance, this loss of repair function can contribute to an overall loss of muscle mass and to progressive muscle weakness (see below).

\section{SATELLITE CELL HETEROGENEITY}

Satellite cells are so named because they associate very closely with muscle fibers, and in fact, satellite cells typically have been defined by their peculiar localization between the basal lamina and plasma membrane (sarcolemma) of muscle fibers (Mauro 1961). Although the adult satellite cell compartment is often thought of as homogeneous, we (Sherwood et al. 2004) and other investigators (Shefer et al. 2004; Kuang et al. 2007) have found that myofiber-associated cells are actually quite heterogeneous and contain both myogenic and nonmyogenic cells. As described in more detail below, our prospective fractionation of myofiber-associated cells, isolated from intact skeletal muscle by two-step enzymatic digestion, indicates that the muscle-forming and non-muscle-forming populations contained in adult muscle can be separated by virtue of their differential expression of the surface proteins CD45 and Sca-1 (data summarized in Table 1). In particular, in vitro differentiation and in vivo transplant assays demonstrate that the Sca $-1^{-} \mathrm{CD} 45^{-}$subset of myofiber-associated cells contains the vast majority of autonomously myogenic cells (Sherwood et al. 2004; Montarras et al. 2005; Kuang et al. 2007; Cerletti et al. 2008; Sacco et al. 2008). These Sca- $1^{-}$CD $45^{-}$cells exhibited no in vitro fibroblastic or adipocytic differentiation potential in any of the in vitro or in vivo studies that we have performed (Sherwood et al. 2004; Cerletti et al. 2008).

In contrast, consistent with recent studies describing the isolation of Sca- $1^{+}$mesenchymal precursor cells from adipose tissue (Rodeheffer et al. 2008; Tang et al. 2008), Sca- $1^{+}$cells purified from skeletal muscle exhibit fibroblastic and adipogenic differentiation upon culture (Sherwood et al. 2004) and after in vivo transplant (M. Cerletti et al., in prep.). Finally, in both resting and injured muscle, $\mathrm{CD} 45^{+}$blood-lineage cells can be detected in the myofiber-associated cell compartment (Sherwood et al. 2004; Cerletti et al. 2008). Like Sca- $1^{+}$cells, these CD $45^{+}$ cells also exhibit no autonomously myogenic activity (Saba 2004; Sherwood et al. 2004; Montarras et al. 2005) and likely represent tissue-resident immune cells. Interestingly, $\mathrm{CD} 45^{+}$cells are replenished from the bloodstream (Table 1), but only slowly, and they remain predominantly host-derived in muscles of parabiotic mice, which exhibit approximately 50\% chimerism of circulating blood leukocytes (Wright et al. 2001). Thus, the normal role of these cells may be to support rapid, local immune and inflammatory responses, equivalent to Langerhans cells in the skin (Merad et al. 2003) and microglia in the brain (Kennedy and Abkowitz 1997).

The close association of these many different cell types with normal muscle fibers suggests that complex interactions among these cells are likely important for normal muscle homeostasis and effective repair. Perturbation of any of these interactions might contribute to muscle dysfunction in disease or following myotrauma. In addition, because the relative representation of myogenic versus nonmyogenic cells within the myofiber-associated satellite cell compartment can change significantly during development, during the course of normal adult life, and in response to pathological muscle conditions, we pro- 
Table 1. Summary of cell-surface-marker expression and functional characterization of myofiber-associated cells in adult, wild-type mice (Sherwood et al. 2004; Cerletti et al. 2008)

\begin{tabular}{|c|c|c|c|c|c|}
\hline $\begin{array}{l}\text { Cell-surface-marker } \\
\text { phenotype }\end{array}$ & $\begin{array}{l}\text { Autonomous } \\
\text { in vitro } \\
\text { myogenicity }\end{array}$ & $\begin{array}{l}\text { In vivo } \\
\text { myogenic } \\
\text { activity }\end{array}$ & $\begin{array}{l}\text { Formation of } \\
\text { fibroblastic } \\
\text { colonies in vitro }\end{array}$ & $\begin{array}{l}\text { In vitro } \\
\text { adipogenic } \\
\text { activity }\end{array}$ & $\begin{array}{l}\text { Can be } \\
\text { seeded from } \\
\text { circulation }\end{array}$ \\
\hline $\begin{array}{l}\text { (1) } \mathrm{CD} 45^{+} \\
\left.\text {(mostly Mac- } 1^{+}\right) \\
\text {(2) } \mathrm{CD}^{-} 45^{-} \mathrm{Sca}-1^{+}\end{array}$ & No & No & No & $\mathrm{N} / \mathrm{D}$ & Yes \\
\hline $\mathrm{CD} 45^{-} \mathrm{Sca}-1^{+} \mathrm{CD} 34^{+}$ & No & No & Yes & Yes & Yes \\
\hline (3) $\begin{array}{l}\mathrm{CD} 45^{-} \mathrm{Sca}-1^{+} \mathrm{CD} 34^{-} \\
\mathrm{CD} 45^{-} \mathrm{Sca}-1 \mathrm{Mac}-1^{-}\end{array}$ & No & No & Yes & $\mathrm{N} / \mathrm{D}$ & Yes \\
\hline $\begin{array}{l}\text { CXCR } 4^{+} \beta 1 \text {-integrin } \\
\left(\text { all are } C D 34^{+}\right)\end{array}$ & Yes & Yes & No & No & No \\
\hline
\end{tabular}

From these data, we propose that the myofiber-associated cell compartment is heterogeneous and contains (1) $\mathrm{CD} 45^{+}$hematopoietic cells, predominantly of the myeloid lineage (Mac-1 $\left.1^{+}\right),(2) \mathrm{CD}_{4} 5^{-} \mathrm{Sca}-1^{+}$cells, including cells with differentiation potential for mesenchymal lineages $\left(\mathrm{CD} 45^{-} \mathrm{Sca}-1^{+} \mathrm{CD} 34^{+}\right)$, and (3) committed muscle stem cells (skeletal muscle precursors [SMPs], CD45 ${ }^{-}$Sca- $1^{-}$Mac- $1^{-}$CXCR4 ${ }^{+} \beta 1$-integrin ${ }^{+}$[CSM4 $\left.\beta\right]$ ). N/D, not done.

pose that age- or disease-induced imbalance in the relative frequencies of myogenic versus nonmyogenic cells in the muscle could contribute to pathological changes in the regenerative responses of injured muscle tissue (Hidestrand et al. 2008).

\section{PROSPECTIVE ISOLATION OF HIGHLY REGENERATIVE MUSCLE-FORMING STEM CELLS}

The ability of skeletal muscle to undergo multiple rounds of regeneration throughout life while still maintaining the satellite cell pool suggests that at least a subset of satellite cells exhibits both self-renewal and differentiation capacities - hallmark properties of tissue stem cells (Collins and Partridge 2005; Wagers and Conboy 2005). To isolate such potential muscle stem cells, we have used cell-surface-marker profiling and fluorescence-activated cell sorting (FACS) to prospectively identify and separate distinct satellite cell populations (Sherwood et al. 2004). This strategy was based on the hypothesis that, as with blood-forming and neural stem cells (Wagers and Weissman 2004), primitive muscle stem cells would express on their surface particular combinations of marker proteins that specifically distinguish them from nonmyogenic cells and from their more differentiated progeny that also may be present in the satellite cell compartment (Wagers and Conboy 2005).

Consistent with this hypothesis, by systematic analysis of more than 40 antibodies recognizing individual cell surface markers, we identified a combination of five markers $\left(\mathrm{CD} 45^{-} \mathrm{Sca}-1^{-} \mathrm{Mac}^{-}{ }^{-} \mathrm{CXCR}^{+} \beta 1\right.$-integrin $\left.{ }^{+}[\mathrm{CSM} 4 \beta]\right)$ that distinguishes a population of myogenic satellite cells with muscle stem cell properties (Sherwood et al. 2004). These cells, which we call skeletal muscle precursors (SMPs), can be sorted from freshly dissociated mouse skeletal muscle tissue (Sherwood et al. 2004) and exhibit very efficient in vitro myogenic differentiation at the single-cell level ( $\sim 50-80 \%$ colony formation from clonally sorted cells; Sherwood et al. 2004) and robust muscle regenerative activity in vivo (Fig. 1) (Sherwood et al. 2004). Significantly, when transferred into the muscle of $m d x$ mice (Sicinski et al. 1989), which model several features of human Duchenne's muscular dystrophy (DMD), SMPs contribute to hundreds of new muscle fibers and support donor cell-derived restoration of expression of the musclespecific protein dystrophin (Cerletti et al. 2008), a protein that is normally absent in $m d x$ animals (Sicinski et al. 1989). The mechanism by which these cells incorporate into muscle involves fusion with both endogenous fibers and myogenic precursors and de novo myogenesis (seen in $\sim 2 \%$ of donor-marker-expressing myofibers) (Cerletti et al. 2008). Moreover, in highly engrafted recipients, incorporation of dystrophin-expressing donor nuclei supported functional improvement of muscle contraction in recipient mice (Cerletti et al. 2008). Finally, unlike differentiated muscle myoblasts, transplanted SMPs also re-seed a reserve pool of muscle precursors within the recipient's muscle (Cerletti et al. 2008). In addition, because this reserve of muscle stem cells remains in the transplanted tissue, it can be recruited again to mediate subsequent rounds of muscle regeneration, providing a renewing source of cells for muscle repair.

Extensive studies from numerous laboratories have defined characteristic properties of skeletal muscle satellite cells (including mitotic quiescence, localization beneath the basal lamina, and expression of the myogenic transcription factors Pax3 and Pax7) (for review, see Wagers and Conboy 2005). To evaluate the relationship of SMPs to canonically defined satellite cells and other described myogenic populations, we also have investigated their molecular and cell biological properties in adult skeletal muscle. Like bulk muscle satellite cells, SMPs are present at differing frequencies in various skeletal muscle beds but absent from cardiac muscle (S. Jurga and A.J. Wagers, unpubl.). When harvested from uninjured muscle, SMPs are largely quiescent (in the $\mathrm{G}_{0} / \mathrm{G}_{1}$ phase of the cell cycle) and express mRNA encoding markers of undifferentiated satellite cells, including the myogenic transcription factors Pax3 and Pax 7 (Cerletti et al. 2008). They do not stain with antibodies against Flk1 or VE-cadherin (markers of vascular endothelial cells), but they do express CD34, which marks both endothelium and satellite cells (Cerletti et al. 2008; S. Jurga and A.J. Wagers, unpubl.). Like satellite cells, CSM4 $\beta$ SMPs do not express markers of differentiated myoblasts, including desmin and myosin heavy chain (MyHC) (Cerletti et al. 2008). Finally, immunostaining of isolated single myofibers indicates expression of the 
CSM4 $\beta$ marker CXCR4 on a subset of sublaminar, Pax $7^{+}$ satellite cells, suggesting that CSM4 $\beta$ SMPs indeed localize to the canonical satellite cell niche (Cerletti et al. 2008).

Taken together, these data indicate that autonomously myogenic skeletal muscle stem cells can be distinguished from nonmyogenic myofiber-associated cells by virtue of their unique expression of the cell-surface-marker profile CSM4 $\beta$. CSM4 $\beta$ SMPs exhibit unique myogenic and stem cell properties and robust muscle regenerative activities. These cells likely represent a major regenerative population in normal adult myogenesis and may be targeted in muscle disease (see below). Therefore, strategies to restore their normal function, either by transplantation (Cerletti et al. 2008) or manipulation of the endogenous SMP population, may provide promising new approaches for the treatment of muscle degenerative disease.

\section{MUSCLE STEM CELLS AND MUSCLE DISEASE}

A large number of genetically distinct, congenital diseases impair the structure and/or function of skeletal muscle, resulting in muscular dystrophy (MD), muscle weakness, and metabolic disorder. In Duchenne MD (DMD), the most common childhood form of MD, the impaired structural integrity of dystrophic myofibers necessitates repeated cycles of precursor-cell-mediated muscle regeneration, resulting in a continual need for satellite cell proliferation. It has been hypothesized that such repeated recruitment of satellite cells to participate in muscle repair may ultimately lead to premature loss or impairment of their myogenic activity (Blau et al. 1983; Wright et al. 1985; Luz et al. 2002). Consistent with this notion, several studies have documented alterations in satellite cell number and/or function associated with muscular dystrophy (Wakayama et al. 1979; Ishimoto et al. 1983; Reimann et al. 2000; Yablonka-Reuveni and Anderson 2006), including in vitro studies indicating an enhanced rate of differentiation among dystrophic $(m d x)$ mouse satellite cells (Yablonka-Reuveni and Anderson 2006). We also have noted a significant age-dependent loss of phenotypically identified SMP muscle stem cells in $m d x$ muscle, although clonal analysis indicated that the myogenic efficiency of SMPs sorted from $m d x$ muscle is equivalent to that of wild-type SMPs (Cerletti et al. 2008). Interestingly, we have observed a similar numeric loss of SMPs in the affected muscles of mice deficient in expression of the membrane repair protein dysferlin (J.L. Shadrach and A.J. Wagers, in prep.). In both mice and humans, dysferlin deficiency causes a relatively lateonset dystrophy (known as limb girdle muscular dystrophy type 2B [LGMD2B] or Miyoshi myopathy in humans) that shows stereotypical involvement of particular muscle groups and is thought to arise from failure to efficiently repair tears in the sarcolemma of muscle fibers (Bashir et al. 1998; Liu et al. 1998; Bansal et al. 2003; Lennon et al. 2003; Bansal and Campbell 2004; Ho et al. 2004). These data, obtained in two different models of muscular dystrophy, suggest that chronic muscle damage can perturb the normal maintenance and regulation of muscle stem cells, leading to accelerated loss of these cells from the muscle and possibly accelerating disease progression. Although the specific molecular processes that induce such alterations in satellite cell homeostasis in dystrophic muscle have yet to be described, we believe that delineating these effects will likely be informative for understanding the progressive pathophysiology of dystrophic disease.

\section{AGING OF SKELETAL MUSCLE STEM CELLS}

In addition to congenital myopathies, the growing incidence of age-related loss of muscle mass and strength (also known as sarcopenia) presents an urgent health concern in both developed and developing countries. Defects in muscle maintenance and function contribute significantly to morbidity and loss of physical independence among the elderly and also predispose to the occurrence of additional age-associated conditions, including increased adiposity, insulin resistance, frailty fracture and falls. Thus, in light of current demographic trends that predict a near doubling of the number of individuals over the age of 65 in the next 20-25 years (U.S. Census Bureau 2004), it is more than ever imperative to develop a clear understanding of the consequences of physiological aging on muscle lineage cells.

In most tissues, aging involves a progressive decline in the ability to maintain homeostatic cell replacement and to regenerate after injury. How aging causes this widespread deterioration of tissue function is poorly understood, but several lines of evidence implicate loss or functional impairment of tissue-specific stem cells in these age-dependent failures (Rossi et al. 2008). For example, the aged hematopoietic system exhibits deregulation of hematopoietic stem cell self-renewal and differentiation, leading to an apparent phenotypic expansion of HSCs that nonetheless exhibit decreased hematopoietic activity and skewed cell-fate determination (Morrison et al. 1996; Liang et al. 2005; Rossi et al. 2005). Similarly, aging of the central nervous system (CNS) impairs the self-renewal activity of neural stem cells, leading to decreased production of new neurons in the neurogenic subventricular zone (SVZ) of aged animals (Enwere et al. 2004; Maslov et al. 2004; Molofsky et al. 2006).

Like the blood and nervous systems, skeletal muscle also appears to suffer deficiencies in precursor cell activity as a result of physiological aging. As muscle ages, its regenerative abilities decline, such that damage to old muscle tissue results less frequently in replacement by new muscle fibers and more frequently in a prolonged inflammatory response and ultimate replacement by fat and fibrous tissue (Conboy et al. 2003, 2005; Brack et al. 2007). This decline in myogenic function leads to progressive muscle wasting, weakness, and slow or absent recovery after injury in elderly individuals (Di Iorio et al. 2006). Although some inconsistencies exist in published literature (Conboy et al. 2003), several studies have reported decreases in the number of muscle satellite cells associated with aged muscle fibers (Shefer et al. 2006; Collins et al. 2007). Consistent with this, flow cytometric analysis indicates an approximately $50 \%$ reduction in the relative frequency of SMPs among myofiber-associated cells isolated from 2-year-old, as opposed to 2-month-old, mice (M. Cerletti et al., in prep.). In addition, satellite cell 
myogenic activity appears to be impaired in old muscle. Aged satellite cells fail to respond appropriately to muscle injury and as a result, may remain quiescent (Conboy et al. 2003) or exhibit perturbed differentiation potential (Brack et al. 2007) even in the face of strong regenerative signals that normally initiate myogenic repair in young tissue. Interestingly, in the skeletal muscle, age-related effects on regenerative cell function appear to arise largely from alterations in the aged muscle environment (Zacks and Sheff 1982; Carlson and Faulkner 1989; Conboy et al. 2005; Carlson et al. 2008) that appear to suppress normal stem cell activity in older animals and can be regulated by factors that circulate naturally in the bloodstream (Brack et al. 2007; Carlson et al. 2008). These findings have important implications for regenerative-medicine approaches in aged individuals. In particular, although identification of the relevant age-related factors that inhibit muscle regeneration in aged animals could provide new strategies to restore or maintain healthy muscle function in aging individuals, alterations in the aged environment could limit the function of young, healthy cells transplanted into aged muscle.

\section{SUMMARY AND PERSPECTIVE}

Adult skeletal muscle maintains remarkable regenerative potential throughout most of life, due predominantly to the presence of self-renewing myogenic stem cells within the canonically defined satellite cell pool. These muscle stem cells can be prospectively isolated, based on combinatorial cell-surface-marker expression, and display unique myogenic and regenerative capabilities. Distinct, nonmyogenic cell populations can also be isolated from the myofiber-associated cell compartment, and these may contribute to local inflammatory responses and support fibrogenic and adipogenic activities in the muscle. Changes in the relative representation of myogenic versus nonmyogenic populations are seen in the context of chronic muscle disease and sarcopenia, and they may reflect proliferative exhaustion of muscle stem cells or inhibitory signals emanating from the dystrophic or aged muscle environment. Future therapeutic strategies based on transplantation of myogenic precursor cells or targeting of endogenous regenerative cells must account for potential modulatory effects of the host environment on effective engraftment and activity of muscle-forming stem cells.

\section{ACKNOWLEDGMENTS}

This work was supported in part by a Burroughs Wellcome Fund career award, a Seed Grant from the Harvard Stem Cell Institute, and a grant from the Jain Foundation (A.J.W.).

\section{REFERENCES}

Armand, O., Boutineau, A.M., Mauger, A., Pautou, M.P., and Kieny, M. 1983. Origin of satellite cells in avian skeletal muscles. Arch. Anat. Microsc. Morphol. Exp. 72: 163-181.

Bansal, D. and Campbell, K.P. 2004. Dysferlin and the plasma membrane repair in muscular dystrophy. Trends Cell Biol. 14: 206-213.
Bansal, D., Miyake, K., Vogel, S.S., Groh, S., Chen, C.C., Williamson, R., McNeil, P.L., and Campbell, K.P. 2003. Defective membrane repair in dysferlin-deficient muscular dystrophy. Nature 423: 168-172.

Bashir, R., Britton, S., Strachan, T., Keers, S., Vafiadaki, E., Lako, M., Richard, I., Marchand, S., Bourg, N., Argov, Z., et al., 1998. A gene related to Caenorhabditis elegans spermatogenesis factor fer-1 is mutated in limb-girdle muscular dystrophy type 2B. Nat. Genet. 20: 37-42.

Birchmeier, C. and Brohmann, H. 2000. Genes that control the development of migrating muscle precursor cells. Curr. Opin. Cell Biol. 12: 725-730.

Bischoff, R. 1994. The satellite cell and muscle regeneration. In Myogenesis (ed. A.G. Engel and C. Franszini-Armstrong), vol. 2, pp. 97-118. McGraw-Hill, New York.

Blau, H.M., Webster, C., and Pavlath, G.K. 1983. Defective myoblasts identified in Duchenne muscular dystrophy. Proc. Natl. Acad. Sci. 80: 4856-4860.

Borycki, A.G., Li, J., Jin, F., Emerson, C.P., and Epstein, J.A. 1999. Pax3 functions in cell survival and in pax7 regulation. Development 126: 1665-1674.

Brack, A.S., Conboy, M.J., Roy, S., Lee, M., Kuo, C.J., Keller, C., and Rando, T.A. 2007. Increased Wnt signaling during aging alters muscle stem cell fate and increases fibrosis. Science 317: 807-810.

Buckingham, M., Bajard, L. Chang, T. Daubas, P., Hadchouel, J., Meilhac, S., Montarras, D., Rocancourt D., and Relaix, F. 2003. The formation of skeletal muscle: From somite to limb. J. Anat. 202: 59-68.

Carlson, B.M. and Faulkner, J.A. 1989. Muscle transplantation between young and old rats: Age of host determines recovery. Am. J. Physiol. 256: C1262-C1266.

Carlson, M.E., Hsu, M., and Conboy, I.M. 2008. Imbalance between pSmad 3 and Notch induces CDK inhibitors in old muscle stem cells. Nature 454: 528-532.

Cerletti, M., Jurga, S., Witczak, C.A., Hirshman, M.F., Shadrach, J.L., Goodyear, L.J., and Wagers, A.J. 2008. Highly efficient, functional engraftment of skeletal muscle stem cells in dystrophic muscles. Cell 134: 37-47.

Collins, C.A. and Partridge, T.A. 2005. Self-renewal of the adult skeletal muscle satellite cell. Cell Cycle 4: 1338-1341.

Collins, C.A., Zammit, P.S., Ruiz, A.P., Morgan, J.E., and Partridge, T.A. 2007. A population of myogenic stem cells that survives skeletal muscle aging. Stem Cells 25: 885-894.

Collins, C.A., Olsen I., Zammit, P.S., Heslop, L., Petrie, A., Partridge, T.A., and Morgan, J.E. 2005. Stem cell function, selfrenewal, and behavioral heterogeneity of cells from the adult muscle satellite cell niche. Cell 122: 289-301.

Conboy, I.M., Conboy, M.J., Smythe, G.M., and Rando, T.A. 2003. Notch-mediated restoration of regenerative potential to aged muscle. Science 302: 1575-1577.

Conboy, I.M., Conboy, M.J., Wagers, A.J., Girma, E.R., Weissman, I.L., and Rando, T.A. 2005. Rejuvenation of aged progenitor cells by exposure to a young systemic environment. Nature 433: 760-764.

Cossu, G., Tajbakhsh, S., and Buckingham, M. 1996a. How is myogenesis initiated in the embryo? Trends Genet. 12: 218-223.

Cossu, G., Kelly R., Tajbakhsh, S., Di Donna, S., Vivarelli, E., and Buckingham, M. 1996b. Activation of different myogenic pathways: myf- 5 is induced by the neural tube and MyoD by the dorsal ectoderm in mouse paraxial mesoderm. Development 122: 429-437.

Daston, G., Lamar, E., Olivier, M., and Goulding, M. 1996. Pax-3 is necessary for migration but not differentiation of limb muscle precursors in the mouse. Development 122: 1017-1027.

Di Iorio, A., Abate, M., Di Renzo, D., Russolillo, A., Battaglini, C., Ripari, P., Saggini, R., Paganelli, R., and Abate G. 2006. Sarcopenia: Age-related skeletal muscle changes from determinants to physical disability. Int. J. Immunopathol. Pharmacol. 19: 703-719.

Enwere, E., Shingo, T., Gregg, C., Fujikawa, H., Ohta, S., and Weiss, S. 2004. Aging results in reduced epidermal growth factor receptor signaling, diminished olfactory neurogenesis, and deficits in fine olfactory discrimination. J. Neurosci. 24: 8354 8365. 
Goulding, M., Lumsden, A., and Paquette, A.J. 1994. Regulation of Pax-3 expression in the dermomyotome and its role in muscle development. Development 120: 957-971.

Gros, J., Manceau, M., Thomé, V., and Marcelle, C. 2005. A common somitic origin for embryonic muscle progenitors and satellite cells. Nature 435: 954-958.

Hidestrand, M., Richards-Malcolm, S., Gurley, C.M., Nolen, G., Grimes, B., Waterstrat, A., Zant, G.V., and Peterson, C.A. 2008. Sca-1-expressing nonmyogenic cells contribute to fibrosis in aged skeletal muscle. J. Gerontol. A Biol. Sci. Med. Sci. 63: 566579.

Ho, M., Post, C.M., Donahue, L.R., Lidov, H.G., Bronson, R.T., Goolsby, H., Watkins, S.C., Cox, G.A., and Brown, Jr., R.H. 2004. Disruption of muscle membrane and phenotype divergence in two novel mouse models of dysferlin deficiency. Hum. Mol. Genet. 13: 1999-2010.

Ishimoto, S., Goto, I., Ohta, M., and Kuroiwa, Y. 1983. A quantitative study of the muscle satellite cells in various neuromuscular disorders. J. Neurol. Sci. 62: 303-314.

Kennedy, D.W. and Abkowitz, J.L. 1997. Kinetics of central nervous system microglial and macrophage engraftment: Analysis using a transgenic bone marrow transplantation model. Blood 90: 986-993.

Kuang, S., Kuroda, K., Le Grand, F., and Rudnicki, M.A. 2007. Asymmetric self-renewal and commitment of satellite stem cells in muscle. Cell 129: 999-1010.

Lennon, N.J., Kho, A., Bacskai, B.J., Perlmutter, S.L., Hyman, B.T., and Brown, Jr., R.H. 2003. Dysferlin interacts with annexins $\mathrm{A} 1$ and $\mathrm{A} 2$ and mediates sarcolemmal wound-healing. $J$. Biol. Chem. 278: 50466-50473.

Liang, Y., Van Zant, G., and Szilvassy, S.J. 2005. Effects of aging on the homing and engraftment of murine hematopoietic stem and progenitor cells. Blood 106: 1479-1487.

Liu, J., Aoki, M., Illa, I., Wu, C., Fardeau, M., Angelini, C., Serrano, C., Urtizberea, J.A., Hentati, F., Hamida, M.B., et al. 1998. Dysferlin, a novel skeletal muscle gene, is mutated in Miyoshi myopathy and limb girdle muscular dystrophy. Nat. Genet. 20: 31-36.

Luz, M.A., Marques, M.J., and Santo Neto, H. 2002. Impaired regeneration of dystrophin-deficient muscle fibers is caused by exhaustion of myogenic cells. Braz. J. Med. Biol. Res. 35: 691-695.

Maslov, A.Y., Barone, T.A., Plunkett, R.J., and Pruitt, S.C. 2004. Neural stem cell detection, characterization, and age-related changes in the subventricular zone of mice. J. Neurosci. 24: $1726-1733$.

Mauro, A. 1961. Satellite cells of muscle skeletal fibers. $J$. Biophys. Biochem. 9: 493-495.

Merad, M., Manz, M.G., Karsunky, H., Wagers, A., Peters, W., Charo, I., Weissman, I.L., Cyster, J.G., and Engelman, E.G. 2002. Langerhans cells renew in the skin throughout life under steady-state conditions. Nat. Immunol. 3: 1135-1141.

Molofsky, A.V., Slutsky, S.G., Joseph, N.M., He, S., Pardal, R., Krishnamurthy, J., Sharpless, N.E., and Morrison, S.J. 2006. Increasing $p 16^{I N K} 4 a$ expression decreases forebrain progenitors and neurogenesis during ageing. Nature 443: 448-452.

Montarras, D., Morgan, J., Collins, C., Relaix, F., Zaffran, S., Cumano, A., Partridge, T., and Buckingham, M. 2005. Direct isolation of satellite cells for skeletal muscle regeneration. Science 309: 2064-2067.

Morrison, S.J., Wandycz, A.M., Akashi, K., Globerson, A., and Weissman, I.L. 1996. The aging of hematopoietic stem cells. Nat. Med. 2: 1011-1016.

Oustanina, S., Hause, G., and Braun, T. 2004. Pax7 directs postnatal renewal and propagation of myogenic satellite cells but not their specification. EMBO J. 23: 3430-3439.

Reimann, J., Irintchev, A., and Wernig, A. 2000. Regenerative capacity and the number of satellite cells in soleus muscles of normal and $m d x$ mice. Neuromuscul. Disord. 10: 276-282.

Relaix, F., Rocancourt, D., Mansouri, A., and Buckingham, M. 2005. A Pax3/Pax7-dependent population of skeletal muscle progenitor cells. Nature 435: 948-953.
Relaix, F., Montarras, D., Zaffran, S., Gayraud-Morel, B., Rocancourt, D., Tajbakhsh, S., Mansouri, A., Cumano, A., and Buckingham, M. 2006. Pax3 and Pax7 have distinct and overlapping functions in adult muscle progenitor cells. J. Cell Biol. 172: 91-102.

Rodeheffer, M.S., Birsoy, K., and Friedman, J.M. 2008. Identification of white adipocyte progenitor cells in vivo. Cell 135: 240-249.

Rossi, D.J., Jamieson, C.H., and Weissman, I.L. 2008. Stems cells and the pathways to aging and cancer. Cell 132: 681-696.

Rossi, D.J., Bryder, D., Zahn, J.M., Ahlenius, H., Sonu, R., Wagers, A.J., and Weissman, I.L. 2005. Cell intrinsic alterations underlie hematopoietic stem cell aging. Proc. Natl. Acad. Sci. 102: 9194-9199.

Saba, J.D. 2004. Lysophospholipids in development: Miles apart and edging in. J. Cell. Biochem. 92: 967-992.

Sacco, A., Doyonnas, R., Kraft, P., Vitorovic, S., and Blau, H.M. 2008. Self-renewal and expansion of single transplanted muscle stem cells. Nature 456: 502-506.

Seale, P., Sabourin, L.A., Girgis-Gabardo, A., Mansouri A., Gruss, P., and Rudnicki, M.A. 2000. Pax7 is required for the specification of myogenic satellite cells. Cell 102: 777-786.

Shefer, G., Wleklinski-Lee, M., and Yablonka-Reuveni, Z. 2004. Skeletal muscle satellite cells can spontaneously enter an alternative mesenchymal pathway. J. Cell Sci. 117: 5393-5404.

Shefer, G., Van de Mark, D.P., Richardson, J.B., and YablonkaReuveni, Z. 2006. Satellite-cell pool size does matter: Defining the myogenic potency of aging skeletal muscle. Dev. Biol. 294: $50-66$.

Sherwood, R.I., Christensen, J.L., Conboy, I.M., Conboy, M.J., Rando, T.A., Weissman, I.L., and Wagers, A.J. 2004. Isolation of adult mouse myogenic progenitors: Functional heterogeneity of cells within and engrafting skeletal muscle. Cell 119: 543-554.

Sicinski, P., Geng, Y., Ryder-Cook, A.S., Barnard, E.A., Darlison, M.G., and Barnard, P.J. 1989. The molecular basis of muscular dystrophy in the $m d x$ mouse: A point mutation. Science 244: $1578-1580$.

Tang, W., Zeve, D., Suh, J.M., Bosnakovski, D., Kyba, M., Hammer, R.E., Tallquist, M.D., and Graff, J.M. 2008. White fat progenitor cells reside in the adipose vasculature. Science 322: 583-586.

Tremblay, P., Dietrich, S., Mericskay, M., Schubert, F.R., Li, Z., and Paulin D. 1998. A crucial role for Pax3 in the development of the hypaxial musculature and the long-range migration of muscle precursors. Dev. Biol. 203: 49-61.

U.S. Census Bureau. 2004. U.S. Interim Projections by Age, Race, and Hispanic Origin. U.S. Government Printing Office, Washington, D.C.

Wagers, A.J. and Conboy, I.M. 2005. Cellular and molecular signatures of muscle regeneration: Current concepts and controversies in adult myogenesis. Cell 122: 659-667.

Wagers, A.J. and Weissman, I.L. 2004. Plasticity of adult stem cells. Cell 116: 639-648.

Wakayama, Y., Schotland, D.L., Bonilla, E., and Orecchio, E. 1979. Quantitative ultrastructural study of muscle satellite cells in Duchenne dystrophy. Neurology 29: 401-407.

Wright, D.E., Wagers, A.J., Gulati, A.P., Johnson, F.L., and Weissman, I.L. 2001. Physiological migration of hematopoietic stem and progenitor cells. Science 294: 1933-1936.

Wright, W.E. 1985. Myoblast senescence in muscular dystrophy. Exp. Cell Res. 157: 343-354.

Yablonka-Reuveni, Z. and Anderson, J.E. 2006. Satellite cells from dystrophic (Mdx) mice display accelerated differentiation in primary cultures and in isolated myofibers. Dev. Dyn. 235: 203-212.

Yablonka-Reuveni, Z., Quinn, L.S., and Nameroff, M. 1987. Isolation and clonal analysis of satellite cells from chicken pectoralis muscle. Dev. Biol. 119: 252-259.

Zacks, S.I. and Sheff, M.F. 1982. Age-related impeded regeneration of mouse minced anterior tibial muscle. Muscle Nerve 5: 152-161. 


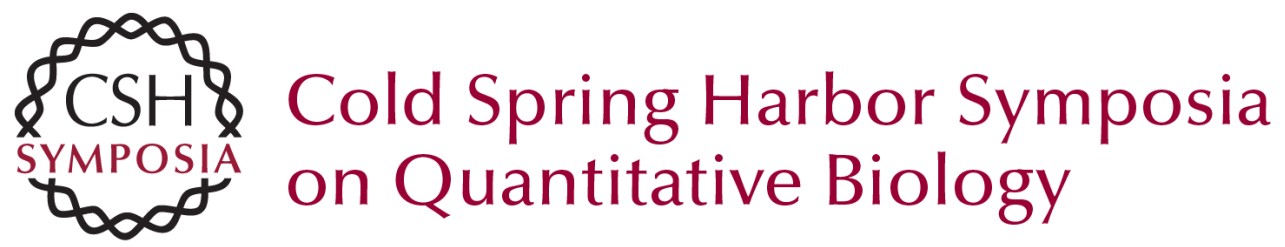

\title{
Regulation and Function of Skeletal Muscle Stem Cells
}

\author{
M. Cerletti, J.L. Shadrach, S. Jurga, et al.
}

Cold Spring Harb Symp Quant Biol 2008 73: 317-322 originally published online February 9, 2009 Access the most recent version at doi:10.1101/sqb.2008.73.054

References This article cites 64 articles, 21 of which can be accessed free at: http://symposium.cshlp.org/content/73/317.full.html\#ref-list-1

License

Email Alerting Receive free email alerts when new articles cite this article - sign up in the box at the Service top right corner of the article or click here. 